\title{
THE DISTRIBUTION OF ASCORBIC ACID BETWEEN CELLS AND SERUM IN RELATION TO ITS URINARY EXCRETION
}

\author{
BY MARTIN HEINEMANN 1 \\ (From the Department of Internal Medicine, Yale University School of Medicine, New Haven)
}

(Received for publication July 14, 1938)

Determinations of the concentration of ascorbic acid in whole blood $(1,2,3,4,5,6,7,8)$ and in plasma or serum $(9,10,11,12,13,14,15,16$, $17,18)$ as well are believed to indicate the degree of saturation of the organism. No strict correlation, however, has been established between the ascorbic acid content of whole blood and of plasma, although the concentration in cells is consistently higher than in plasma under ordinary conditions (5). The present investigation deals with the distribution of ascorbic acid in blood before and during absorption of test doses of ascorbic acid, the relationship of its concentration in whole blood and in serum to the amounts eliminated in urine. The distribution between cells and serum of ascorbic acid added to blood in vitro has also been observed.

\section{METHODS}

Ascorbic acid was determined according to the method of Emmerie and van Eekelen $(1,19,20)$. Instead of oxalated blood, blood defibrinated by stirring with a glass rod was used in order to prevent hemolysis, which influences the content of ascorbic acid in serum or plasma. In the absence of hemolysis no significant nor consistent differences could be detected between oxalated or defibrinated samples of the same blood.

By this method, ascorbic acid in blood is determined by titration against 2,6-dichlorophenol indophenol after deproteinization with trichloroacetic acid and removal of interfering substances by precipitation with mercuric acetate. Since this method has not been described in the American literature, some details are given here.

Reagents.

Trichloroacetic acid, 10 per cent

Mercuric acetate, 20 per cent, prepared according to the directions given in a recent publication (23)

Solid calcium carbonate

Procedure. In whole blood, ascorbic acid has been found to be fairly stable, since it appears to be protected against irreversible oxidation by the red cells $(21,22)$. An interval of a few hours between the collection of blood and the determination of ascorbic acid, therefore, is irrelevant. Ten cc. of defibrinated whole blood and an equal volume of 10 per cent trichloroacetic acid are

\footnotetext{
1 Foreign Physicians' Committee Fellow.
}

mixed thoroughly in a $50 \mathrm{cc}$. round bottomed centrifuge tube by stirring with a glass rod; thereafter, one-half the volume $(5 \mathrm{cc}$.) of 20 per cent mercuric acetate is added and also mixed well. The mixture is neutralized with $\mathrm{CaCO}_{3}$ with Congo red paper as an indicator, and immediately centrifuged for about 2 minutes. The supernatant fluid is then filtered off. The procedure from this point (treatment with $\mathrm{H}_{2} \mathrm{~S}$, which is removed the next day by nitrogen, and titration with 2,6-dichlorophenol indophenol) is similar to that recently described for urine (23). Scarborough and Stewart (24) observed that ascorbic acid, as determined by this method, increased if $\mathrm{H}_{2} \mathrm{~S}$ was removed one or two days later. In view of these observations, it must be mentioned that our specimens have been treated with nitrogen regularly between 17 and 21 hours after treatment with $\mathrm{H}_{2} \mathrm{~S}$. The time elapsing between deproteinization with trichloroacetic acid and treatment of the filtrate with $\mathrm{H}_{2} \mathrm{~S}$ should not exceed 10 minutes, otherwise irreversible oxidation of the vitamin takes place. Loss of time can be reduced by preparing for the different manipulations beforehand and by using a centrifuge equipped with a brake. The quality of $\mathrm{CaCO}_{3}$ has been found to be of importance; some brands may contain reducing substances which are not precipitated by mercuric acetate, giving a blank reading equivalent to $6 \mathrm{mgm}$. of ascorbic acid per $1000 \mathrm{cc}$. With the brand used, Mallinckrodt's analytical reagent, the blank proved to be zero; if high blanks are obtained, the $\mathrm{CaCO}_{3}$ should be suspected.

By this method ascorbic acid, added in amounts from 5 to $10 \mathrm{mgm}$. per liter to whole blood, has been recovered with a maximum error of 10 per cent in 8 experiments.

Providing that food rich in vitamin $\mathrm{C}$ is avoided, only slight fluctuations of ascorbic acid (from 13.1 to 14.8 $\mathrm{mgm}$. per liter) were observed in the blood of a single subject examined 13 times in the course of 30 hours.

Serum. In plasma or serum, ascorbic acid is less stable than in whole blood $(10,13,21,22)$; therefore these fluids have been analyzed immediately after separation from the cells. The procedure is similar to that for whole blood, but less trichloroacetic acid is required for deproteinization. To $10 \mathrm{cc}$. of serum, $5 \mathrm{cc}$. of 10 per cent trichloroacetic acid and $5 \mathrm{cc}$. of mercuric acetate are added. When only 8 or $6 \mathrm{cc}$. of serum are available, the quantities of reagents are reduced proportionally, but the final volume is made up to $20 \mathrm{cc}$. by addition of distilled water in order to yield two $5 \mathrm{cc}$. aliquots for titration. This addition of distilled water, after neutralization with $\mathrm{CaCO}_{s}$ and before centrifuging, does not influence the experimental results. 
In urine. Ascorbic acid has been determined according to the method recently described in full detail (23). For the purpose of observing the excretion of large amounts of ascorbic acid by saturated normal subjects following a test dose direct titration of freshly voided urine is satisfactory.

Blood cell volumes have been measured by the hematocrit method described by Eisenman et al. (25).

In additional experiments in vitro ascorbic acid was not added directly to whole blood, but was dissolved in serum first to avoid hemolysis. No hemolysis occurred nor were changes of cell volume noticed during the experimental period of 5 hours, providing that the amounts added did not exceed $6 \mathrm{mgm}$. per liter. After addition of ascorbic acid the blood was gently shaken mechanically for 4 to 5 hours at $23^{\circ} \mathrm{C}$. in sealed tubes of pyrex glass. Crystalline ascorbic acid has been used.2

\section{RESULTS}

\section{Relationship between the concentrations of ascorbic acid in whole blood and in serum}

Figure 1 shows that in subjects who have not received vitamin $C$ for about 12 hours the concentrations of ascorbic acid in serum are only roughly correlated with those in whole blood and

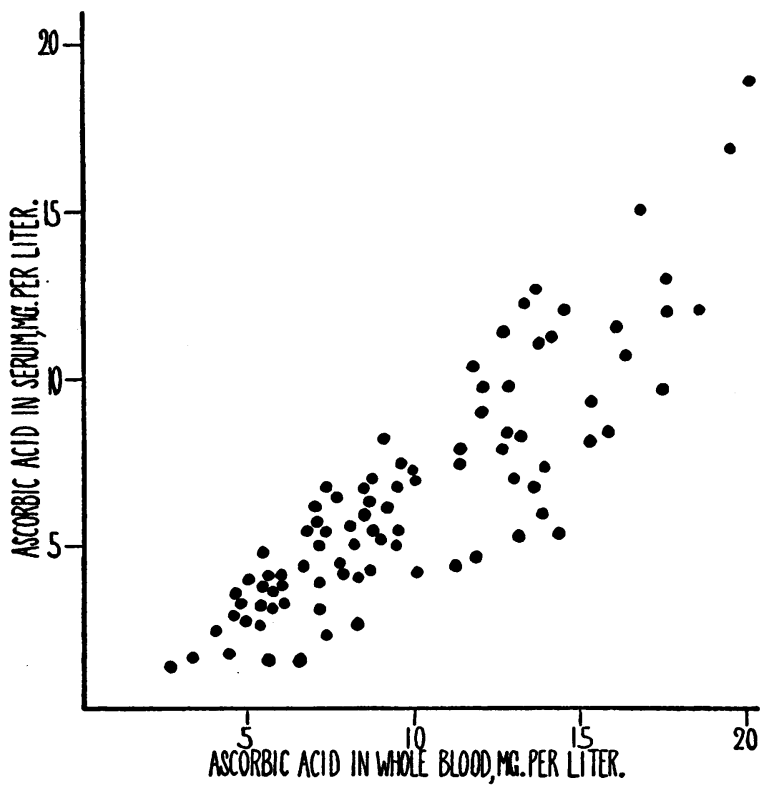

Fig. 1. Relation between Ascorbic Actd in Whole Blood and in Serum in Persons Who Had Received No Vitamin C for at least 12 Hours

2 For the in vitro experiments and for the in vivo studies as well, ascorbic acid was supplied through the courtesy of Hoffman-LaRoche, Inc., Nutley, N. J. that the concentration is always higher in whole blood than in serum.

New data, presented in Figure 2, confirm the almost linear relationship described by van Eekelen et al. (3) between the concentration of ascorbic acid in whole blood and the amount needed for saturation, which has been defined in a previous communication (26).

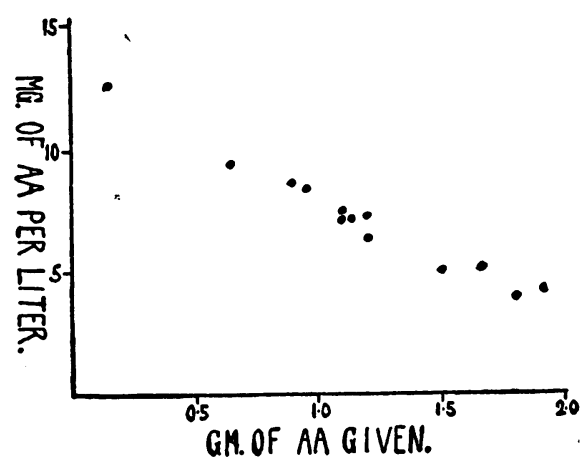

Fig. 2. Relation between the Concentration of Ascorbic Acid in Whole Blood and the Amounts Needed for Saturation

From this it follows that, for the practical estimation of the degree of saturation or unsaturation of an individual, analyses of whole blood are preferable to that of serum. This is further evidenced by the following reactions of a patient. With $13.0 \mathrm{mgm}$. per liter of whole blood and 8.3 $\mathrm{mgm}$. per liter of serum, she excreted $24 \mathrm{mgm}$. of ascorbic acid in the urine in 6 hours following a dose of $300 \mathrm{mgm}$. of ascorbic acid per os; while one week later, with $14.2 \mathrm{mgm}$. per liter in the whole blood and only $5.3 \mathrm{mgm}$. per liter in the serum, she excreted $46 \mathrm{mgm}$. in the same period after the same dose. This patient bled severely between the first and the second experiment. Following several blood transfusions, the serum ascorbic acid of a patient with secondary anemia rose from $3.9 \mathrm{mgm}$. per liter to $6.2 \mathrm{mgm}$. per liter, while the whole blood ascorbic acid remained unchanged (7.1 and $7.0 \mathrm{mgm}$. per liter respectively). These observations illustrate that striking exceptions from the general correlation between whole blood and serum concentrations can occur.

That the concentration in serum may rise above that of whole blood after administration of ascorbic acid is apparent from Table I which pre- 
TABLE I

Milligrams of ascorbic acid per liter of whole blood and serum at intervals after taking ascorbic acid by mouth

\begin{tabular}{|c|c|c|c|c|c|c|c|c|c|}
\hline \multirow{2}{*}{ Intake } & & \multirow{2}{*}{ Before } & \multicolumn{7}{|c|}{ Hours after intake } \\
\hline & & & 1 & $1 \frac{1}{2}$ & 2 & 3 & 4 & 6 & 24 \\
\hline $\begin{array}{c}\underset{\text { per }}{\operatorname{mggm}} . \\
3.0\end{array}$ & $\begin{array}{l}\text { Blood } \\
\text { Serum }\end{array}$ & $\begin{array}{l}14.4 \\
14.0\end{array}$ & $\begin{array}{l}15.6 \\
16.7\end{array}$ & & $\begin{array}{l}17.4 \\
19.5\end{array}$ & $\begin{array}{l}19.0 \\
21.2\end{array}$ & $\begin{array}{l}19.3 \\
20.1\end{array}$ & $\begin{array}{l}17.4 \\
18.9\end{array}$ & \\
\hline 15.0 & $\begin{array}{l}\text { Blood } \\
\text { Serum }\end{array}$ & $\begin{array}{l}4.8 \\
2.7\end{array}$ & & $\begin{array}{l}6.0 \\
5.3\end{array}$ & & $\begin{array}{r}9.8 \\
12.0\end{array}$ & & & $\begin{array}{l}6.8 \\
5.5\end{array}$ \\
\hline
\end{tabular}

sents data from two experiments typical of 13 in which doses from 120 to $1100 \mathrm{mgm}$. of ascorbic acid were taken. Absorption of quantities that cause considerable increase of blood ascorbic acid does not change the cell volume. The concentration of ascorbic acid in serum first rises above that in whole blood but reaches a peak and begins to fall while the concentration in whole blood still continues to rise (see also Figure 4).

Calculations of concentrations of ascorbic acid in blood cells

In the experiments in which cell volume measurements are available, the concentrations of ascorbic acid per liter of cells have been calculated. Figure 3 presents the relationship between ascorbic acid concentrations in cells and in serum in fasting blood.

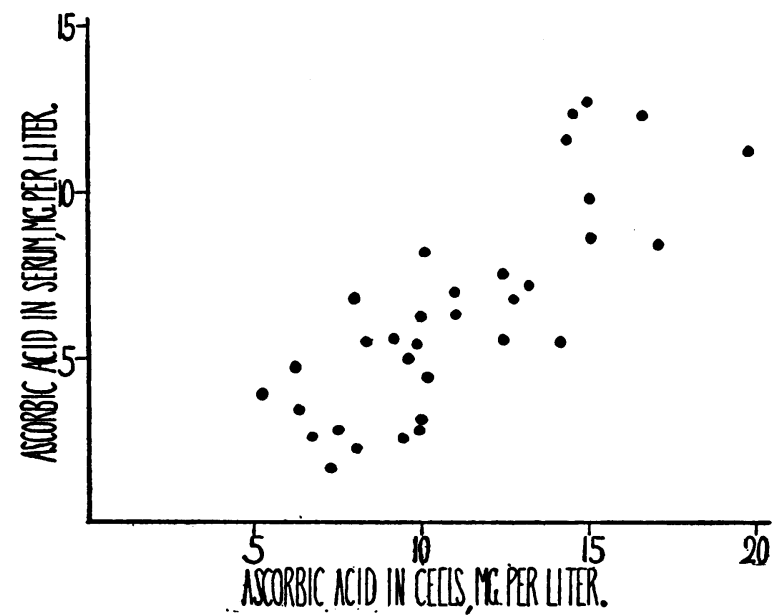

Fig. 3. Relation between Ascorbic Acid in Cells and in Serum in Persons Who Had Received No Vitamin C for at Least 12 Hours
TABLE II

The amounts of ascorbic acid in cells and serum after taking ascorbic acid by mouth

\begin{tabular}{|c|c|c|c|c|c|}
\hline \multirow{2}{*}{ Intake } & \multirow{2}{*}{$\begin{array}{c}\text { Time } \\
\text { after } \\
\text { intake }\end{array}$} & \multirow{2}{*}{ Cell volume } & \multicolumn{3}{|c|}{ Ascorbic acid } \\
\hline & & & $\begin{array}{l}\text { Whole } \\
\text { blood }\end{array}$ & Serum & Cells \\
\hline $\begin{array}{c}\underset{k g m}{\operatorname{mgm}} \text {. per } \\
2\end{array}$ & $\begin{array}{c}\text { hours } \\
3\end{array}$ & $\begin{array}{c}\text { per cent } \\
50\end{array}$ & $\begin{array}{c}\underset{\text { liter }}{\text { mgm. per }} \\
20.3\end{array}$ & $\begin{array}{c}\underset{\text { liter }}{\text { mgm. per }} \\
22.8\end{array}$ & $\begin{array}{c}\text { mgm. per } \\
\text { liter } \\
17.8\end{array}$ \\
\hline 2 & 3 & 48 & 16.3 & 18.3 & 14.2 \\
\hline 2 & 5 & 38 & 14.4 & 15.9 & 11.8 \\
\hline 2 & 3 & 38 & 15.3 & 17.7 & 11.3 \\
\hline 15.5 & $\begin{array}{l}0 \\
1^{\frac{1}{2}}\end{array}$ & $\begin{array}{l}45 \\
45 \\
45\end{array}$ & $\begin{array}{l}4.8 \\
6.0 \\
9.8\end{array}$ & $\begin{array}{r}2.7 \\
5.3 \\
12.0\end{array}$ & $\begin{array}{l}7.3 \\
6.9 \\
7.1\end{array}$ \\
\hline 10.0 & $\begin{array}{l}0 \\
2\end{array}$ & $\begin{array}{l}43 \\
43\end{array}$ & $\begin{array}{r}9.4 \\
11.7\end{array}$ & $\begin{array}{r}6.8 \\
14.3\end{array}$ & $\begin{array}{r}12.8 \\
8.1\end{array}$ \\
\hline 12.0 & $\begin{array}{l}0 \\
2\end{array}$ & $\begin{array}{l}43 \\
44\end{array}$ & $\begin{array}{r}9.8 \\
18.1\end{array}$ & $\begin{array}{r}7.2 \\
25.5\end{array}$ & $\begin{array}{r}13.3 \\
8.6\end{array}$ \\
\hline 8.0 & 0 & 43 & 8.7 & 5.5 & 13.0 \\
\hline $\begin{array}{l}4.0 \\
5.0\end{array}$ & $\begin{array}{l}3^{\frac{1}{2}} \\
6\end{array}$ & $\begin{array}{l}43 \\
43\end{array}$ & $\begin{array}{l}14.1 \\
16.3\end{array}$ & $\begin{array}{l}17.5 \\
17.5\end{array}$ & $\begin{array}{r}9.5 \\
14.7\end{array}$ \\
\hline 3.5 & $\begin{array}{l}0 \\
1 \frac{1}{2} \\
2 \frac{1}{2} \\
3 \frac{1}{2} \\
5\end{array}$ & $\begin{array}{l}39 \\
39 \\
39 \\
39 \\
39\end{array}$ & $\begin{array}{l}13.2 \\
14.3 \\
15.0 \\
17.6 \\
18.1\end{array}$ & $\begin{array}{l}12.3 \\
15.2 \\
17.5 \\
20.1 \\
18.5\end{array}$ & $\begin{array}{l}14.6 \\
12.8 \\
11.0 \\
13.6 \\
17.4\end{array}$ \\
\hline 2 & $\begin{array}{l}2 \frac{1}{2} \\
4 \\
5 \\
6 \frac{1}{2}\end{array}$ & $\begin{array}{l}39 \\
39 \\
39 \\
39\end{array}$ & $\begin{array}{l}16.4 \\
16.0 \\
18.6 \\
17.6\end{array}$ & $\begin{array}{l}20.0 \\
20.0 \\
20.0 \\
18.2\end{array}$ & $\begin{array}{r}10.8 \\
9.7 \\
16.4 \\
16.7\end{array}$ \\
\hline 2 & $\begin{array}{l}3 \\
6\end{array}$ & $\begin{array}{l}38 \\
38\end{array}$ & $\begin{array}{l}15.1 \\
14.9\end{array}$ & $\begin{array}{l}16.8 \\
15.9\end{array}$ & $\begin{array}{l}12.4 \\
13.2\end{array}$ \\
\hline 3.5 & $\begin{array}{l}0 \\
1 \\
2 \\
3 \\
4 \frac{1}{2}\end{array}$ & $\begin{array}{l}36 \\
36 \\
36 \\
36 \\
36\end{array}$ & $\begin{array}{l}14.4 \\
15.6 \\
17.4 \\
19.0 \\
19.3\end{array}$ & $\begin{array}{l}14.0 \\
16.7 \\
19.5 \\
21.2 \\
20.1\end{array}$ & $\begin{array}{l}15.0 \\
13.6 \\
13.6 \\
15.0 \\
17.8\end{array}$ \\
\hline 10.0 & $\begin{array}{l}0 \\
1 \frac{1}{2} \\
3 \\
4 \frac{1}{2} \\
6 \\
8 \frac{1}{2} \\
14 \\
24\end{array}$ & $\begin{array}{l}36 \\
36 \\
37 \\
36 \\
36 \\
36 \\
36 \\
37\end{array}$ & $\begin{array}{l}4.5 \\
6.6 \\
8.7 \\
9.0 \\
7.8 \\
7.8 \\
6.8 \\
6.6\end{array}$ & $\begin{array}{l}3.5 \\
6.9 \\
8.3 \\
9.9 \\
9.0 \\
7.5 \\
5.7 \\
5.4\end{array}$ & $\begin{array}{l}6.3 \\
6.1 \\
9.5 \\
7.5 \\
5.6 \\
8.3 \\
8.9 \\
8.6\end{array}$ \\
\hline 10 & $\begin{array}{l}0 \\
1 \frac{1}{2} \\
3 \frac{1}{2} \\
6 \\
7 \frac{1}{2}\end{array}$ & $\begin{array}{l}36 \\
36 \\
36 \\
36 \\
36\end{array}$ & $\begin{array}{l}11.7 \\
15.7 \\
19.9 \\
18.4 \\
17.5\end{array}$ & $\begin{array}{l}10.4 \\
16.3 \\
24.1 \\
22.2 \\
19.9\end{array}$ & $\begin{array}{l}13.9 \\
14.7 \\
12.5 \\
11.7 \\
13.3\end{array}$ \\
\hline 2 & $\begin{array}{l}0 \\
3 \\
6\end{array}$ & $\begin{array}{l}36 \\
36 \\
36\end{array}$ & $\begin{array}{l}18.0 \\
19.1 \\
17.8\end{array}$ & $\begin{array}{l}17.6 \\
21.0 \\
18.6\end{array}$ & $\begin{array}{l}18.6 \\
15.8 \\
16.4\end{array}$ \\
\hline
\end{tabular}


Figure 3 demonstrates that (i) a general correlation exists between the ascorbic acid concentrations of serum and cells, and that (ii) the latter are consistently higher. These experiments, too small in number to justify statistical treatment, also indicate that the line going through the averages is not a straight one; at increasing ascorbic acid levels, a trend towards a rise in serum concentrations, approaching equilibrium with those in the cells, is observed. The distribution of ascorbic acid does not seem to depend on the cell volumes.

After ingestion of ascorbic acid the concentration in serum rises above that in cells. Apparently ascorbic acid gains access to the cells from serum only at a slow rate (Table II).

\section{Relationship between the concentration of ascorbic acid in whole blood and serum and its elimination in the urine}

When following a test dose of ascorbic acid, taken by saturated subjects, the urinary elimination and the concentrations in whole blood and in serum are observed, the highest rate of excretion appears to coincide with the highest concentration in whole blood and cells and occurs approximately 1 to 2 hours after the concentration in the serum has reached its peak. Figure 4 presents the data from two such experiments which are typical for all seven conducted. Assuming a normal (inulin) clearance of $140 \mathrm{cc}$. per minute (27) for the subject on whom the experiment was

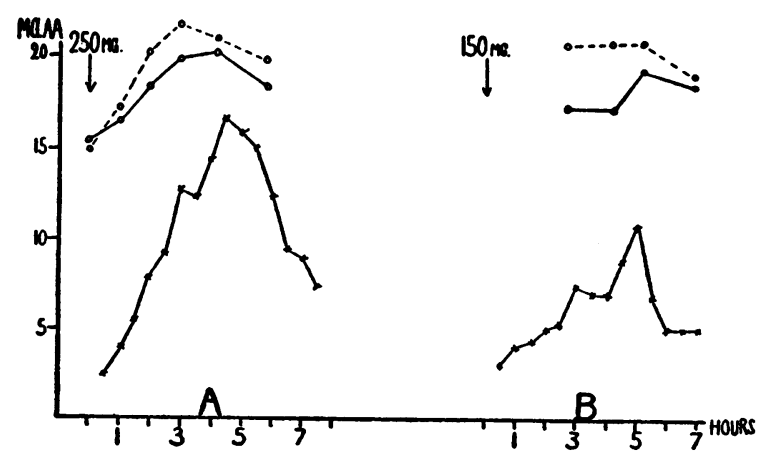

Fig. 4. Relation of Ascorbic Acid in Whole Blood AND In Serum to ITS URINARy Excretion

Arrows indicate the time of administration of ascorbic acid. $\mathbf{x} \longrightarrow \mathbf{x}$ represents $\mathrm{mgm}$. of ascorbic acid in urine; $0 \_$and $\mathrm{o}-\ldots-0 \mathrm{mgm}$. of ascorbic acid per liter of whole blood and serum respectively. carried out, we have calculated the amounts of ascorbic acid reabsorbed per minute (Table III). The calculated concentrations of ascorbic acid per liter of cells are also presented.

TABLE III

The mode of excretion of administered ascorbic acid

\begin{tabular}{c|c|c|c|c|c|c}
\hline \hline $\begin{array}{c}\text { Time } \\
\text { after } \\
\text { intake }\end{array}$ & $\begin{array}{c}\text { Ascorbic } \\
\text { acid in } \\
\text { plasma }\end{array}$ & $\begin{array}{c}\text { Clear- } \\
\text { ance } \\
\text { (inulin) }\end{array}$ & $\begin{array}{c}\text { Ascorbic } \\
\text { acid } \\
\text { filtered } \\
\text { in } \\
\text { glomeruli }\end{array}$ & $\begin{array}{c}\text { Ascorbic } \\
\text { acid } \\
\text { excreted } \\
\text { in } \\
\text { urine }\end{array}$ & $\begin{array}{c}\text { Ascorbic } \\
\text { acid re- } \\
\text { absorbed }\end{array}$ & $\begin{array}{c}\text { Ascorbic } \\
\text { acid } \\
\text { in } \\
\text { blood } \\
\text { cells }\end{array}$ \\
\hline hours & $\begin{array}{c}\text { mgm.per } \\
\text { liter }\end{array}$ & $\begin{array}{c}\text { liter per } \\
\text { minute }\end{array}$ & $\begin{array}{c}\text { mgm. per } \\
\text { minute }\end{array}$ & $\begin{array}{c}\text { mgm. per } \\
\text { minute }\end{array}$ & $\begin{array}{c}\text { mgm. per } \\
\text { minute }\end{array}$ & $\begin{array}{c}\text { mgm. per } \\
\text { liter }\end{array}$ \\
a) & & & & & & \\
1 & 16.5 & 0.140 & 2.30 & 0.10 & 2.20 & 13.8 \\
$1 \frac{1}{2}$ & 18.0 & 0.140 & 2.52 & 0.15 & 2.37 & 14.1 \\
2 & 19.5 & 0.140 & 2.73 & 0.23 & 2.50 & 14.1 \\
$2 \frac{1}{2}$ & 20.3 & 0.140 & 2.84 & 0.28 & 2.56 & 14.9 \\
3 & 21.0 & 0.140 & 2.94 & 0.40 & 2.54 & 15.7 \\
$3 \frac{1}{2}$ & 20.5 & 0.140 & 2.87 & 0.40 & 2.47 & 16.5 \\
4 & 20.2 & 0.140 & 2.83 & 0.46 & 2.37 & 17.8 \\
$4 \frac{1}{2}$ & 19.8 & 0.140 & 2.77 & 0.53 & 2.24 & 17.6 \\
5 & 19.5 & 0.140 & 2.73 & 0.50 & 2.23 & 16.8 \\
$5 \frac{1}{2}$ & 19.0 & 0.140 & 2.66 & 0.45 & 2.21 & 16.2 \\
& & & & & & \\
$b)$ & & & & & \\
3 & 20.0 & 0.140 & 2.80 & 0.20 & 2.60 & 10.5 \\
$3 \frac{1}{2}$ & 20.0 & 0.140 & 2.80 & 0.20 & 2.60 & 10.5 \\
4 & 20.0 & 0.140 & 2.80 & 0.23 & 2.57 & 10.5 \\
$4 \frac{1}{2}$ & 20.0 & 0.140 & 2.80 & 0.27 & 2.53 & 13.5 \\
5 & 20.0 & 0.140 & 2.80 & 0.30 & 2.50 & 15.9 \\
$5 \frac{1}{2}$ & 19.5 & 0.140 & 2.73 & 0.21 & 2.52 & 16.5 \\
6 & 19.0 & 0.140 & 2.66 & 0.16 & 2.50 & 16.2 \\
$6 \frac{1}{2}$ & 18.5 & 0.140 & 2.59 & 0.13 & 2.46 & 17.1 \\
& & & & & & \\
\hline
\end{tabular}

a) from Figure $4 \mathrm{~A}$.

b) from Figure $4 \mathrm{~B}$.

These calculations show a steady increase in ascorbic acid reabsorbed per minute until 4 to 5 hours have passed, when, coincident with a further increase in urinary excretion, tubular reabsorption diminishes significantly. In 5 other similar experiments in which sufficient data are available for the calculations, the same phenomena are observed.

Under suitable conditions, after a saturated subject has taken a single dose of about $2 \mathrm{mgm}$. of ascorbic acid per kgm. of body weight per os, the curve of excretion in the urine may assume a biphasic form. Figure 5, Number I, is typical of 7 experiments, the first peak, about 3 hours from the start of the experiment, coincides with the highest serum concentration; the second, approximately 3 hours later, marks the point when the concentration in whole blood has reached a maximum, and occurs when the concentration in serum is decreasing (Figure 4A) or constant (Figure $4 \mathrm{~B}$ ). 


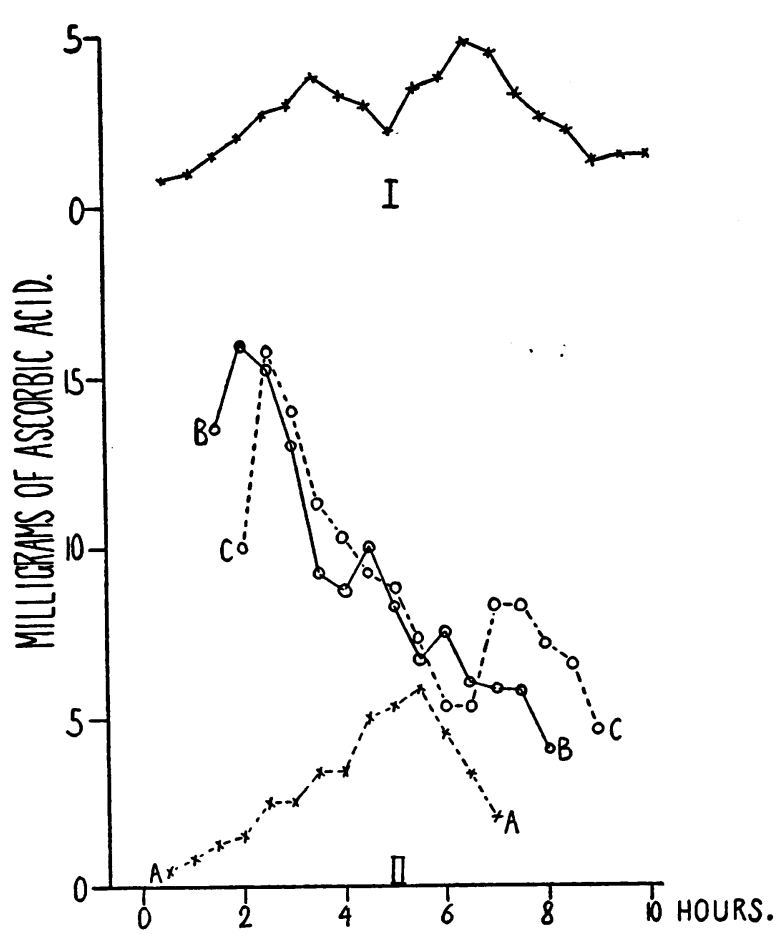

Fig. 5. Conditions Influencing the Mode of ExCRETION OF AsCORBIC ACID

In all the experiments $2 \mathrm{mgm}$. per $\mathrm{kgm}$. of body weight of ascorbic acid were taken at $\mathbf{0}$ hours. I. After breakfast with coffee; II A. After 500 cc. of milk, II B and II $\mathrm{C}$ in the postabsorptive condition.

As stated before, this biphasic excretion in urine can be observed under very special conditions only. Not only must the subject be saturated and the dose carefully chosen, but the time intervening between the dose and the preceding feeding must be controlled. In the 2 subjects studied, the biphasic excretion occurred consistently when the ascorbic acid was given onehalf to one hour after a breakfast of cereal, buttered bread, and sweetened coffee. When the ascorbic acid was taken while the subject was in the postabsorptive state, the first peak appeared earlier and was more pronounced, while the second peak was lower (Figure $5 \mathrm{C}$ ) or absent (Figure $5 \mathrm{~B}$ ), presumably owing to accelerated absorption. When ascorbic acid was taken one hour after $500 \mathrm{cc}$. of cold milk, a single peak was noted $5 \frac{1}{2}$ hours later (Figure $5 \mathrm{~A}$ ), probably because absorption was so slow that a distinct peak in the serum concentration did not occur. From all these experiments it is evident that ab- sorption of ascorbic acid begins within an hour and continues for at least $4 \frac{1}{2}$ to 5 hours following ingestion.

In an unsaturated subject, the avidity of depleted tissues for vitamin $\mathrm{C}$ is such that after administration of as much as $750 \mathrm{mgm}$. of ascorbic acid in a single dose the initial low concentrations in whole blood (4.8 mgm. per liter) and serum (3.0 mgm. per liter) never rose above the threshold levels ; consequently, the urinary excretion remained quite unaffected.

The transient rise of the serum concentration above that in whole blood, however, occurs also in unsaturated subjects, if large doses are given.

\section{Uptake of ascorbic acid by blood cells in vitro}

The data from in vivo experiments already presented indicate that ascorbic acid is not distributed in the blood immediately, but that it permeates the cells slowly.

From the results presented in Table IV, Numbers 1 and 2, typical of 6 such experiments, it follows that in vitro also ascorbic acid is taken up by blood cells but slowly. Essentially the same changes are observed when ascorbic acid is not

TABLE IV

Distribution of ascorbic acid added to defibrinated blood in vitro

\begin{tabular}{|c|c|c|c|c|c|}
\hline \multirow{2}{*}{$\begin{array}{l}\text { Ascorbic } \\
\text { acid } \\
\text { added }\end{array}$} & \multirow{2}{*}{$\begin{array}{c}\text { Time } \\
\text { after } \\
\text { addition }\end{array}$} & \multirow{2}{*}{ Cell volume } & \multicolumn{3}{|c|}{ Ascorbic acid } \\
\hline & & & $\begin{array}{l}\text { Whole } \\
\text { blood }\end{array}$ & Serum & Cells \\
\hline$\underset{\text { liter }}{\text { mgm. per }}$ & hours & per cent & $\underset{\text { liter }}{\text { mgm. per }}$ & $\underset{\text { liter }}{\text { mgm. per }}$ & $\underset{\text { liter }}{\text { mgm. per }}$ \\
\hline 1. 5.3 & $\begin{array}{l}0 \\
1^{\frac{1}{2}} \\
2 \\
3 \frac{1}{2}\end{array}$ & $\begin{array}{l}45 \\
45 \\
45 \\
45 \\
45\end{array}$ & $\begin{array}{r}9.4 \\
14.1 \\
14.5 \\
14.5 \\
14.5\end{array}$ & $\begin{array}{r}5.5 \\
16.4 \\
15.5 \\
15.0 \\
13.5\end{array}$ & $\begin{array}{l}14.2 \\
11.3 \\
13.3 \\
13.8 \\
15.8\end{array}$ \\
\hline 2. 6.2 & $\begin{array}{l}0 \\
2^{\frac{1}{2}} \\
3 \\
4\end{array}$ & $\begin{array}{l}40 \\
40 \\
40 \\
40 \\
40\end{array}$ & $\begin{array}{r}9.9 \\
15.9 \\
15.5 \\
15.9 \\
15.5\end{array}$ & $\begin{array}{r}7.0 \\
15.8 \\
15.8 \\
14.9 \\
13.9\end{array}$ & $\begin{array}{l}14.3 \\
16.0 \\
15.0 \\
17.5 \\
18.0\end{array}$ \\
\hline \multicolumn{6}{|l|}{ 3.* } \\
\hline$a$ & $\begin{array}{l}0 \\
4 \frac{1}{2}\end{array}$ & $\begin{array}{l}47 \\
47\end{array}$ & $\begin{array}{l}20.0 \\
19.5\end{array}$ & $\begin{array}{l}19.0 \\
17.0\end{array}$ & $\begin{array}{l}21.1 \\
22.3\end{array}$ \\
\hline$b$ & $\begin{array}{l}0 \\
4 \frac{1}{2}\end{array}$ & $\begin{array}{l}48 \\
48\end{array}$ & $\begin{array}{l}18.0 \\
18.5\end{array}$ & $\begin{array}{l}18.0 \\
15.5\end{array}$ & $\begin{array}{l}18.0 \\
21.7\end{array}$ \\
\hline
\end{tabular}

* Blood taken $1 \frac{1}{2}$ hours $(a)$ and 5 hours $(b)$ after intake of one gram of ascorbic acid. 
added to the shed blood in vitro, but is taken by the donor of the blood prior to the venipuncture (Table IV, Number 3).

\section{DISCUSSION}

\section{Distribution of ascorbic acid in blood}

The distribution of ascorbic acid between cells and serum of fasting blood in our experiments is in essential agreement with other observations $(5,28,29)$; the concentration of ascorbic acid in cells is larger than in serum or plasma when calculated for equal volumes. The observations of Pijoan and Eddy (30) were taken on cells that had been washed with saline three or four times. They noted higher values in serum than in the washed cells but failed to recognize the fact that in the washing of the cells ascorbic acid is withdrawn from the cell itself (31), yielding values of lower magnitude in the assay of this organic acid in blood corpuscles. This view has recently been confirmed by personal communication with these investigators. Confirming the results of earlier studies (5), it has been observed that the amounts of ascorbic acid in cells are not consistently proportional to those in serum; gener-. ally, as concentrations of ascorbic acid in whole blood decrease, the ratio

\section{concentration of ascorbic acid in cells concentration of ascorbic acid in serum,}

always greater than 1 in fasting blood, rises (Figure 3). The distribution of ascorbic acid between serum and cells, therefore, depends to some extent on the higher or lower concentration of the vitamin in the blood. The observations following ingestion of ascorbic acid, presented in Table II and Figure 4, demonstrate that the concentrations of ascorbic acid in serum and in cells fluctuate more than the concentration in whole blood. The exchange between the ascorbic acid present in serum and that in cells causes considerable variations in the concentrations of ascorbic acid in either one during the postabsorptive state. It is the resultant of both these factors, namely whole blood, which indicates most reliably the degree of saturation in relation to the amounts of the vitamin excreted in urine. Since a certain amount of vitamin is regularly ingested with normal food, the determination of this vitamin in whole blood is to be recommended also in subjects not fully saturated, since following ingestion of amounts contained in the meals, similar although less pronounced fluctuations in serum and cell concentrations occur. Evidently for this reason, Wright and MacLenathen (32) withhold any vitamin $\mathrm{C}$ for 2 days prior to the determination of ascorbic acid in serum. Furthermore, striking exceptions from the general, but not obligatory, correlation between the ascorbic acid concentrations in whole blood and in serum also support the contention that ascorbic acid should be determined in whole blood rather than in serum. That the whole blood content actually indicates the degree of saturation or depletion has been demonstrated by evaluating the doses needed for saturation in individuals with different whole blood levels (Figure 2). Similar observations have been published recently by Neuweiler (8).

\section{The influence of ascorbic acid concentration in serum, whole blood, and cells on the rate of urinary elimination}

From the data presented in Figure 4 it is evident that the rate of urinary elimination of ascorbic acid, following intake of a moderate test dose by a saturated subject, does not depend solely on the concentration of the vitamin in serum (i), but is influenced by some other factor (ii) also. (i) The rate of urinary elimination of ascorbic acid rises together with, but more steeply than the concentration of ascorbic acid in serum and does not fall as soon as the concentration in the serum decreases. (ii) The peak of urinary excretion of ascorbic acid coincides invariably with the peak of the concentration in whole blood.

Ralli et al. (33) showed that at very high levels of plasma ascorbic acid following intravenous injection, this vitamin is probably completely filtered in the glomeruli ${ }^{3}$ and a maximal tubular reabsorptive capacity of 2.4 to $2.8 \mathrm{mgm}$. per minute is possible. At lower serum concentrations, following intake of ascorbic acid by mouth, similar rates of reabsorption were observed (Table III). From the data presented in Table III, it follows

\footnotetext{
8 In the kidney of the frog, Leblond (34) could exclude the possibility of tubular secretion of ascorbic acid and demonstrate that urinary elimination of this vitamin is effected entirely by glomerular filtration.
} 
that two essentially different phases of urinary excretion of ascorbic acid can be distinguished. Shortly after intake of ascorbic acid at rising serum concentrations, tubular reabsorption does not increase as rapidly as glomerular filtration. Consequently, the amounts both reabsorbed and excreted rise. The largest excretion of ascorbic acid in urine, however, occurs in a second phase during which the serum concentrations remain constant or decline. Increased glomerular filtration can, therefore, be excluded as a cause for the increasing excretion during this period. Table III shows that this further rise in the excretion of the vitamin, in spite of constant or diminishing amounts filtered in the glomeruli, occurs simultaneously with a decrease in reabsorption. It is during this period that the ascorbic acid concentration in the blood corpuscles reaches a peak. It might be conceived that the reaction of the cells of the renal tubules toward ascorbic acid is similar to that of the blood cells. The diminished rate of reabsorption may be referable to the increasing concentration of ascorbic acid in the renal cells. This increase in the ascorbic acid concentration may take considerable time as does the entrance of ascorbic acid into blood corpuscles. It is reasonable to believe that the fall in power of reabsorption, related to augmented concentrations of ascorbic acid in the kidney cells, accounts for the excretory peaks that have been found to coincide with the highest concentration of ascorbic acid in blood cells at high serum levels. Since high concentrations of ascorbic acid in red cells have been observed also at lower serum levels (Figure 3), raised concentrations in both cells and serum seem to be the phenomena in blood which really characterize saturation in the strictest sense, conditions under which maximal amounts of ascorbic acid are stored in the organism and any further intake is rapidly eliminated by the kidney. No evidence is available concerning the magnitude of the amounts of ascorbic acid in the kidney under the conditions of our experiments. The ascorbic acid content of the kidney is probably the more important factor for the excretion of vitamin $C$ under normal circumstances, with concentrations of the vitamin near to the saturation level; the ascorbic acid concentration in serum assumes increasing importance for the urinary elimination when it is increased suddenly to a considerable extent by parenteral administration or by massive doses per os, especially during the postabsorptive state. Actually, the urinary excretion at a given moment is owing probably to the combined influences of both these factors. At present, the interpretation outlined above can not be substantiated by further experimental evidence.

\section{Uptake of ascorbic acid by blood cells in vitro}

Borsook et al. (22) present data which they interpret as indicating impermeability of erythrocytes to ascorbic acid added to blood in vitro, during one hour. Their data, however, agree closely with ours; after one hour the cells take up an insignificant or hardly demonstrable amount of the substance. When the observations are extended to four hours, however, it becomes evident that ascorbic acid slowly penetrates the cells. The experiments were not complicated by hemolysis.

No explanation is offered for the transient fall in the concentration of ascorbic acid in cells noted both in vitro and in vivo when the concentration in serum is increased suddenly. This phenomenon is most marked when the initial levels are high. The changes are beyond the limits of error of the method, which is not more than 10 per cent, and will be the subject of further investigation.

This discussion and the conclusions drawn from the experiments presented assume that the method applied is specific for ascorbic acid, a supposition supported by experimental evidence $(7,19,20,35)$. Mirsky et al. (36), who found that whole blood values did not agree with the presumable state of saturation, failed to treat their filtrates with nitrogen long enough to completely remove $\mathrm{H}_{2} \mathrm{~S}$, which interferes with the titration.

\section{CONCLUSIONS AND SUMMARY}

In fasting blood, a general correlation exists between the ascorbic acid concentrations in cells and in serum; the concentrations in cells consistently exceed those in serum. Concentrations greater in serum than in cells are observed transiently following absorption of ascorbic acid, when 
the exchange between vitamin $\mathrm{C}$ in serum and cells causes fluctuations in their concentrations. These fluctuations are more marked in both cells and serum than in their resultant, whole blood. The whole blood concentration of ascorbic acid appears to correspond almost lineally to the degree of saturation of experimental subjects; it also closely indicates the different phases of complete saturation produced by test doses of ascorbic acid, as measured by the amounts excreted in urine. Serum and whole blood concentrations are only roughly correlated. Therefore, the determination of ascorbic acid in whole blood is to be preferred for practical purposes.

The urinary elimination of large amounts of ascorbic acid following intake of a test dose by saturated subjects, depends on its concentration in the serum and on the amounts filtered therefrom in the glomeruli, and the rate of tubular reabsorption. The relations between the curve of excretion and the concentrations in cells and serum suggest that the rate of reabsorption by the tubule cells may depend upon the concentration of ascorbic acid in these cells.

Ascorbic acid is taken up from the plasma by red cells both in vivo and in vitro at a slow rate.

\section{BIBLIOGRAPHY}

1. Emmerie, A., and van Eekelen, M., The chemical determination of vitamin $C$ with removal of interfering reducing and coloured substances. Biochem. J., 1934, 28, 1153.

2. van Eekelen, M., On the amount of ascorbic acid in blood and urine. The daily human requirements for ascorbic acid. Biochem. J., 1936, 30, 2291.

3. van Eekelen, M., Emmerie, A., and Wolff, L. K., Ueber die Diagnostik der Hypovitaminosen $A$ und $C$ durch die Bestimmung dieser Vitamine im Blut. Ztschr. f. Vitaminforsch., 1937, 6, 151.

4. Deggeller, O., Onderzoekingen over het gehalte aan vitamine C van het bloed. Thesis Utrecht, 1936, Drukkerij Fa. Schotanus and Jens, Utrecht.

5. Heinemann, M., On the partition of ascorbic acid between plasma and erythrocytes. Acta brev. Neerland., 1936, 6, 139.

6. Heinemann, M. I., On the relation between diet and urinary output of thiosulphate (and ascorbic acid). II. Human requirements for vitamin C. Biochem. J., 1936, 30, 2299.

7. Ferrari, R., and Buogo, G., Simplifications in the determination of ascorbic acid. Arch. di fisiol., 1935, 35, 125 (cited from Nutrition Abstr. and Rev.. 1937, 6, 649).
8. Neuweiler, W., Ueber den Nachweis des Vitamin-C Sättigungsgrades des Organismus. Ztschr. f. Vitaminforsch., 1938, 7, 128.

9. Gabbe, E., Bestimmung von Vitamin C im Blutserum. Klin. Wchnschr., 1934, 13, 1389.

10. Farmer, C. J., and Abt, A. F., Ascorbic acid content of blood. Proc. Soc. Exper. Biol. and Med., 1935, $32,1625$.

11. Greenberg, L. D., Rinehart, J. F., and Phatak, N. M., Studies on reduced ascorbic acid content of the blood plasma. Proc. Soc. Exper. Biol. and Med., 1936, 35, 135.

12. Taylor, F. H. L., Chase, D., and Faulkner, J. M., The estimation of reduced ascorbic acid in blood serum and plasma. Biochem. J., 1936, 30, 1119.

13. Pijoan, M., Townsend, S. R., and Wilson, A., Determination of reduced ascorbic acid in blood. Proc. Soc. Exper. Biol. and Med., 1936, 35, 224.

14. Pijoan, M., and Klemperer, F., Determination of blood ascorbic acid. J. Clin. Invest., 1937, 16, 443.

15. Mindlin, R. L., and Butler, A. M., The determination of ascorbic acid in plasma; a macromethod and micromethod. J. Biol. Chem., 1938, 122, 673.

16. Portnoy, B., and Wilkinson, J. F., Vitamin $C$ deficiency in peptic ulceration and haematemesis. Brit. M. J., 1938, 1, 554.

Intradermal test for vitamin $\mathrm{C}$ deficiency. Ibid., 328.

17. Lund, H., and Lieck, H., A test for ascorbic acid in serum by means of a methylene blue reaction. Skandinav. Arch. f. Physiol., 1936, 74, 269.

Quantitative Bestimmung von Ascorbinsäure im Blutserum. Klin. Wchnschr., 1937, 16, 555.

18. Elmby, A., and With, T. K., Methode zur Bestimmung der Serumascorbinsäure mit Capillarblut. Die Methylenblaumethode (Lund und Lieck) als “ Mikromethode." Klin. Wchnschr., 1937, 16, 746.

19. van Eekelen, M., and Emmerie, A., Some critical remarks on the determination of ascorbic acid. Biochem. J., 1936, 30, 25.

20. Emmerie, A., and van Eekelen, M., The determination of ascorbic acid in blood. Biochem. J., 1937, 31, 2125.

21. Kellie, A. E., and Zilva, S. S., The catalytic oxidation of ascorbic acid. Biochem. J., 1935, 29, 1028.

22. Borsook, H., Davenport, H. W., Jeffreys, C. E. P., and Warner, R. C., The oxidation of ascorbic acid and its reduction in vitro and in vivo. J. Biol. Chem., 1937, 117, 237.

23. van Eekelen, M., and Heinemann, M., Critical remarks on the determination of urinary excretion of ascorbic acid. J. Clin. Invest., 1938, 17, 293.

24. Scarborough, H., and Stewart, C. P., Observations on the excretion of ascorbic acid in urine. Biochem. J., 1937, 31, 2232.

25. Eisenman, A. J., Mackenzie, L. B., and Peters, J. P., Protein and water of serum and cells of human blood, with a note on the measurement of red blood cell volumes. J. Biol. Chem., 1936, 116, 33. 
26. Heinemann, M., Requirements for vitamin $C$ in man. J. Clin. Invest., 1938, 17, 671.

27. Smith, H. W., Goldring, W., and Chasis, H., The measurement of the tubular excretory mass, effective blood flow and filtration rate in the normal human kidney. J. Clin. Invest., 1938, 17, 263.

28. Schneider, E., and Widmann, E., Blutserum und Bluteiweisskörper und Vitamin C. Klin. Wchnschr., 1935, 14, 1454.

29. Stephens, D. J., and Hawley, E. E., The partition of reduced ascorbic acid in blood. J. Biol. Chem., 1936, 115, 653.

30. Pijoan, M., and Eddy, E., Ascorbic acid content of red cells and plasma. J. Lab. and Clin. Med., 1937, 22, 1227.

31. Heinemann, M., and Heinemann, G., Unpublished studies.

32. Wright, I. S., and MacLenathen, E., Vitamin C saturation-kidney retention after an intravenous test dose of ascorbic acid. Proc. Soc. Exper. Biol. and Med., 1938, 38, 55.

33. Ralli, E. P., Friedman, G. J., and Rubin, S. H., The mechanism of vitamin $\mathrm{C}$ excretion in man studied by simultaneous vitamin $\mathrm{C}$ and inulin clearances. J. Clin. Invest. (Proc.), 1938, 17, 504.

34. Leblond, C. P., Mécanisme de l'élimination rénale de la vitamine C. Compt. rend. Soc. de Biol., 1938, 127, 208.

35. Manceau, P., Policard, A., and Ferrand M., Remarques sur le dosage chimique de l'acide ascorbique. II. Etude critique des procédés de purification. Application au dosage dans l'urine. Bull. Soc. chim. biol., 1936, 18, 1623.

36. Mirsky, I. A., Swadesh, S., and Soskin, S., Total ascorbic acid content of human blood. Proc. Soc. Exper. Biol. and Med., 1935, 32, 1130. 